\title{
A descriptive cross-sectional study to assess prevalence of mal-nutrition in children under five years age in rural community Bikaner, Rajasthan
}

\author{
Rekha Acharya*, Rattiram Meena
}

Department of Preventive and Social Medicine Sardar Patel Medical College, Bikaner, Rajasthan, India

Received: 18 November 2015

Accepted: 17 December 2015

\section{*Correspondence:}

Dr. Rekha Acharya,

E-mail: drrattirammeena@gmail.com

Copyright: (c) the author(s), publisher and licensee Medip Academy. This is an open-access article distributed under the terms of the Creative Commons Attribution Non-Commercial License, which permits unrestricted non-commercial use, distribution, and reproduction in any medium, provided the original work is properly cited.

\section{ABSTRACT}

Background: Malnutrition among children below five years continues to be one of India major human development challenges. In spite of tremendous economic progress made in the last two to three decades. The objective of the study was to assess prevalence of mal-nutrition in children under five years age in rural community Bikaner, Rajasthan.

Methods: The study was cross-sectional community based study. The study was conducted in village udairamsar in Bikaner rural. It is a Rural Health Training Centre Sardar Patel Medical College Bikaner. Under five year children with sample size of 657 was taken for study.

Results: It was observed that out of 657 children, 367(55.86\%) were males and maximum (22.83\%) children were belong 48-59months age group. All three parameters of malnutrition i.e. wasting, underweight and stunting were more common in males $(21.80 \%, 37.06 \%$, and $29.16 \%$ respectively) than females $(16.55 \%, 26.21 \%$ and $21.72 \%$ respectively). Highest proportion (25.19\%) of wasting was found in age group 36-47 months followed by age 12 to 23 months $(23.88 \%)$.

Conclusions: Majority of under five children were malnourished and malnutrition common in males than females.

Keywords: Malnutrition, Wasting, Stunting, Underweight, Children

\section{INTRODUCTION}

Malnutrition is defined as a pathological state resulting from absolute or relative deficiency or excess of one or more of the nutrients that are considered essential for normal life. ${ }^{1}$

Malnutrition among children below five years continues to be one of India major human development challenges. In spite of tremendous economic progress made in the last two to three decades. Malnutrition among children in rural India still claims many lives. However, mounting cases of malnutrition has caught the public eye and so healthcare providers as well as the government are taking the necessary steps to improve the current status of nutrition for children in India.

According to UNICEF to Pneumonia (30\%) and Diarrhoea $(27 \%)$ are directly related to over $50 \%$ childhood deaths. $35 \%$ of all deaths was caused because child was undernourished. ${ }^{2}$ There is high under five morbidity and mortality in India. ${ }^{3}$ Protein energy malnutrition is major contributory factor in majority of these childhood morbidities and mortalities. At present $65 \%$ under five children are underweight which includes $47 \%$ moderate and $18 \%$ severe case of malnutrition (UNICEF 2006 state of words children). ${ }^{4}$ 


\section{Need of study}

In the purview of above mentioned facts it is well obvious that undernutrition is a serious concern for our nation. It jeopardizes children survival, health, growth and development. They are much more likely to suffer from a serious infection and die from common childhood illnesses such as diarrhoea, measles, and pneumonia. Therefore there is a felt need to study undernutrition and its epidemiology in depth.

\section{METHODS}

The study was cross-sectional community based study. The study was conducted in village udairamsar in Bikaner rural. It is a Rural Health Training Centre Sardar Patel Medical College Bikaner. Under five year children with sample size of 657 was taken for study.

Anthropometric measurements were carried out following standard methods. The data included weight, recumbent length (for children less than 24 months of age) and height (for children more than 24 months of age). Weight was measured to the nearest $0.1 \mathrm{~kg}$ and salter weighing machine was used for weight measurement. Height was measured against a nonstretchable tape fixed toa vertical wall with the participant standing on level of surface and it was measured to the nearest $0.5 \mathrm{~cm}$. Recumbent length was measured by using an infant measuring board. Socioeconomic status was determined by using modified Prasad scale. ${ }^{5}$

Standard statistical method was used in the analysis of the data with use of MS Excel and EPi-info software 3.4.3. $\mathrm{P}$ value was used to examine the relation between variable. Data of the nutritional survey were analysed using WHO Anthro for personal computer, version 3.1.2010.

WHO classification was used for the assessment of malnutrition. Based on age, body weight and height, a number of indices such as height-for-age, weight-for-age and weight-for-height have been suggested. ${ }^{7}$ The children are classified using three categories: underweight (low weight for age), stunting (low height for age) or wasting (low weight for height). Low anthropometric values are those more than 2 SD away from the CDC 2000 (centres for disease control and prevention) standards. ${ }^{7-9}$

\section{RESULTS}

It was observed that out of 657 children, $367(55.86 \%)$ were males and maximum $(22.83 \%)$ children were belong 48-59 months age group.

As shown in the above table highest proportion $(25.19 \%)$ of wasting was found in age group 36-47 months followed by age 12 to 23 months (23.88\%). Wasting among age group 24 to 35 months was only $8.33 \%$.
Similarly underweight children were highest (38.00\%) in age group 48 to 59 months followed by age group 24 to 35 months ye(36.67\%). Highest $38.33 \%$ of stunted children were found in age group 24-35 months followed by $30.67 \%$ in age group 48 to59months. The statistical association between age and wasting and stunting was found to be very significant and highly significant respectively whereas the same between age and underweight was not significant.

Table 1: Distribution on demographical profile.

\begin{tabular}{|c|c|c|c|}
\hline Variable & $\begin{array}{l}\text { Level of } \\
\text { variable }\end{array}$ & frequency & $\%$ \\
\hline \multirow[t]{6}{*}{ Age(months) } & $0-6$ months & 42 & 6.39 \\
\hline & $\begin{array}{l}6 \text { to } \\
11 \text { months }\end{array}$ & 76 & 11.57 \\
\hline & $\begin{array}{l}12 \text { to } \\
23 \text { months }\end{array}$ & 134 & 20.40 \\
\hline & $\begin{array}{l}24 \text { to } 35 \\
\text { months }\end{array}$ & 120 & 18.26 \\
\hline & $\begin{array}{l}36 \text { to } 47 \\
\text { months }\end{array}$ & 135 & 20.55 \\
\hline & $\begin{array}{l}48 \text { to } 59 \\
\text { months }\end{array}$ & 150 & 22.83 \\
\hline \multirow[t]{2}{*}{ Gender } & male & 367 & 55.86 \\
\hline & female & 290 & 44.14 \\
\hline \multirow[t]{2}{*}{ Religion } & Hindu & 602 & 91.63 \\
\hline & Muslim & 55 & 8.3 \\
\hline \multirow[t]{2}{*}{$\begin{array}{l}\text { Mother } \\
\text { education }\end{array}$} & Educated & 307 & 46.72 \\
\hline & $\begin{array}{l}\text { Non } \\
\text { educated }\end{array}$ & 350 & 53.27 \\
\hline \multirow[t]{5}{*}{$\begin{array}{l}\text { Socio- } \\
\text { economic } \\
\text { status class }\end{array}$} & I & 6 & 0.91 \\
\hline & II & 78 & 11.87 \\
\hline & III & 202 & 30.75 \\
\hline & IV & 370 & 56.32 \\
\hline & $\mathrm{V}$ & 1 & 0.15 \\
\hline
\end{tabular}

Table 2: Occurrence of malnutrition in children by age.

\begin{tabular}{|lllll|}
\hline $\begin{array}{l}\text { Age in } \\
\text { months }\end{array}$ & $\begin{array}{l}\text { Mal- } \\
\text { nourishment } \\
\text { present }\end{array}$ & $\begin{array}{l}\text { Mal- } \\
\text { nourishment } \\
\text { absent }\end{array}$ & $\%$ & total \\
\hline $0-5$ & 11 & 31 & 26.19 & 42 \\
\hline $6-11$ & 24 & 52 & 31.58 & 76 \\
\hline $12-23$ & 65 & 69 & 48.51 & 134 \\
\hline $24-35$ & 63 & 57 & 52.50 & 120 \\
\hline $35-47$ & 62 & 73 & 45.93 & 135 \\
\hline $48-59$ & 69 & 81 & 46.00 & 150 \\
\hline total & 294 & 363 & 44.75 & 657 \\
\hline$X^{2}$ & 15.034 & & & \\
\hline df & 5 & & & \\
\hline P value & $<0.05$ & & & \\
\hline
\end{tabular}


Table 3: Occurrence of wasting, underweight and stunting in children by age.

\begin{tabular}{|llllllllllll|}
\hline $\begin{array}{l}\text { Age in } \\
\text { months }\end{array}$ & $\begin{array}{l}\text { Wasting } \\
\text { yes }\end{array}$ & no & $\%$ & $\begin{array}{l}\text { Underweight } \\
\text { yes }\end{array}$ & no & $\%$ & $\begin{array}{l}\text { Stunting } \\
\text { yes }\end{array}$ & no & $\%$ & Total \\
\hline $0-5$ & 5 & 37 & 11.90 & 9 & 33 & 21.43 & 05 & 37 & 11.90 & 42 \\
\hline $6-11$ & 18 & 58 & 23.68 & 16 & 60 & 21.05 & 04 & 72 & 5.26 & 76 \\
\hline $12-23$ & 32 & 102 & 23.88 & 39 & 95 & 29.10 & 35 & 99 & 26.12 & 134 \\
\hline $24-35$ & 10 & 110 & 8.33 & 44 & 76 & 36.67 & 46 & 74 & 38.33 & 120 \\
\hline $36-47$ & 34 & 101 & 25.19 & 47 & 88 & 34.81 & 34 & 101 & 25.19 & 135 \\
\hline $48-59$ & 29 & 121 & 19.33 & 57 & 93 & 38.00 & 46 & 104 & 30.67 & 150 \\
\hline total & 128 & 529 & 19.48 & 212 & 445 & 32.27 & 170 & 487 & 25.88 & 657 \\
\hline$X^{2}$ & 16.354 & & & 10.963 & & & 32.652 & & & \\
\hline df & 5 & & 5 & & & 5 & & & & \\
\hline P value & $<0.01$ & & NS & & & & & & & & \\
\hline
\end{tabular}

$\mathrm{NS}=$ not significant

Table 4: Occurrence of malnutrition in children by gender.

\begin{tabular}{|lllll|}
\hline Age in year & Malnourishment present & Malnourishment absent & $\%$ & total \\
\hline Male & 179 & 188 & 48.77 & 367 \\
\hline female & 115 & 175 & 39.66 & 290 \\
\hline total & 294 & 363 & 44.75 & 657 \\
\hline $\mathrm{X}^{2}$ & 5.448 & & & \\
\hline df & 1 & & & \\
\hline P value & $<0.05$ & & & \\
\hline
\end{tabular}

Table 5: Occurrence of wasting, underweight and stunting in children by gender.

\begin{tabular}{|c|c|c|c|c|c|c|c|c|c|c|}
\hline $\begin{array}{l}\text { Age in } \\
\text { years }\end{array}$ & $\begin{array}{l}\text { Wasting } \\
\text { yes }\end{array}$ & no & $\%$ & $\begin{array}{l}\text { Underweight } \\
\text { yes }\end{array}$ & no & $\%$ & $\begin{array}{l}\text { Stunting } \\
\text { yes }\end{array}$ & no & $\%$ & Total \\
\hline Male & 80 & 287 & 21.80 & 136 & 231 & 37.06 & 107 & 260 & 29.16 & 367 \\
\hline female & 48 & 242 & 16.55 & 76 & 214 & 26.21 & 63 & 227 & 21.72 & 290 \\
\hline total & 128 & 529 & 19.48 & 212 & 445 & 32.27 & 170 & 487 & 25.88 & 657 \\
\hline $\mathrm{X}^{2}$ & 2.843 & & & 8.726 & & & 4.664 & & & \\
\hline df & 1 & & & 1 & & & 1 & & & \\
\hline $\mathrm{P}$ value & NS & & & $<0.01$ & & & $<0.05$ & & & \\
\hline
\end{tabular}

$\mathrm{NS}=$ not significant

All three parameters of malnutrition i.e. wasting, underweight and stunting were more common in males $(21.80 \%, 37.06 \%$, and $29.16 \%$ respectively) than females ( $16.55 \%, 26.21 \%$ and $21.72 \%$ respectively). It was found that there was very significant and highly significant difference with regard to underweight and stunting respectively between male and female children but no significant gender difference was found for wasting.

\section{DISCUSSION}

Protein calories malnutrition is a widespread nutritional disease in developing countries. ${ }^{10}$ As well as mentioned by Gupta et al. ${ }^{11}$ Under five year children are notoriously fraught with the risk of malnutrition and the prevalence of malnutrition varies between $50-80 \%$. Majority of the children in our study were suffering from protein energy malnutrition. A larger proportion of males were suffering malnutrition as compared to females. Out of 294 malnourished children 179 were males and 115 were female. The same result were found in the study of Zottarelli LK, Mittal et al, and Sengupta et al. ${ }^{12-14}$

In present study the total numbers of children below 6 months of age were $6.39 \%$ and between 6-11 months were $11.57 \%$. The maximum number of children was there in 48-59 months of age groups i.e. $22.83 \%$ followed by $36-47$ months age group. Total numbers of children in 12-23 months of age group were $20.40 \%$. The present 
study showed that about $26.19 \%$ babies were malnourished in 0-5 months of age groups. Similar result was found in NFHS III 2005-06 reports. The main reason behind malnutrition among $0-5$ months age group are low birth weight, prelacteals and inadequate breast feeding praccices. In present study 48-59 months old child had the highest proportion of underweight (38\%) Sengupta $\mathrm{P}$ et al observed the similar results. ${ }^{14}$

It was found in study that malnourishment in the form of underweight was most common (32\%) in the study sample followed by stunting $(25.88 \%)$ and wasting (19.48\%). similar proportion of wasted children was reported in NFHS-3 (national as well as of Rajasthan) whereas according to NFHS-3, proportion of underweight and stunted children differed nationally as state-wise (43\%, 48\% in India respectively; $40 \%, 44 \%$ in Rajasthan respectively).

\section{CONCLUSION}

Majority of under five children were malnourished and malnutrition common in males than females.

\section{Recommendations}

Health care providers to focus on health education among parents especially in mothers on the exact nutritional requirements in terms of quality and quantity of the child at specific age groups.

Funding: No funding sources

Conflict of interest: None declared

Ethical approval: The study was approved by the Institutional Ethics Committee

\section{REFERENCES}

1. Park JE, Park K. Park textbook of preventive of social medicine $19^{\text {th }}$ Edition. Jabalpur Banarsidas Bhanol, 2007.

2. Undernutritions impact on child death by illness (internet) UNICEF. Cited 2013 July 13. Available from: http://www.unicef.org/nutrition/2.2/4.html.
3. Park JE, Park K. Park textbook of preventive of social medicine $18^{\text {th }}$ Edition. Jabalpur Banarsidas Bhanol, 2005.

4. Progress for children. A report card nutrition UNICEF: Times of India, 2006.

5. Kumar P. Social classification needs constant upgrading. Ind. J. Comm. Med. 1993;18(2):60-1.

6. Software for assessing growth and development of the WHO 2010. Available from htpp://www. Who.int/childgrowth/software/en.

7. Waterlow IC, Buzina R, Keller W. Presentation and use of height and weight data comparing the nutritional status of groups of children under age 10 years. Bull World Health organ. 1977;55(4):489-98.

8. Kuczmaksi RJ, Ogden CL, Guo SS. CDC Growth Charts for the United States: methods and development. Vital Health Stat. 2002;11(246):1-190.

9. WHO Expert Committee on physical status: the use and interpretation of anthropometry, report of a WHO exp committee, Geneva. Available from http://whqlibdoc.who.int/trs/WHO_TRS_854.

10. Chakraborty S, Gupta SB, Chaturvedi SK. A study of protein energy malnutrition in children in rural area. Indian journal of Community Medicine. 2006:31(4):291-2.

11. Gupta VM, Shukla KK. Epidemiological correlates of protein energy malnutrition in preschool children. Ind J Prev Soc Med. 1992;23:26-32.

12. Zottarelli LK, Sunil TS. Influence of prenatal and socioeconomic factors on stunting in children under 5 years in Egypt. East Meditter Health J. 2007;13(6):1330-42.

13. Mittal A, Singh J. Effect of maternal factors on nutrition status of 1-5 years children in urban slum population. Indian $\mathbf{J}$ community Med Oct. 2007;32(4):264-7.

14. Sengupta P, Philip N. Epidemiological correlates of undernutrition in under 5 year children an slum of Ludhiana. Health and population: perspective and issues. 2010;33(1):1-9.

Cite this article as: Acharya R, Meena R. A descriptive cross-sectional study to assess prevalence of mal-nutrition in children under five years age in rural community Bikaner, Rajasthan. Int J Community Med Public Health. 2016;3:299-302. 